\title{
Curriculum Evaluation in Online Education: The case of Teacher Candidates Preparing Online for Public Personnel Selection Examination
}

\author{
Ömer Cem Karacaoğlu ${ }^{1}$ \\ ${ }^{1} \mathrm{PhD}$ in Curriculum and Instruction, Turkey \\ Correspondence: Ömer Cem Karacaoğlu, PhD in Curriculum and Instruction, Turkey
}

Received: February 9, 2018

Accepted: March 12, 2018

Online Published: March 22, 2018

doi:10.5430/ijhe.v7n2p107

URL: https://doi.org/10.5430/ijhe.v7n2p107

\begin{abstract}
The aim of the present study is to evaluate the efficiency of an online curriculum based on the views of lecturers and students enrolled in the program. The study is mainly based on survey method. In order to collect qualitative data, interviews forms developed by the researcher were used. The reliability and validity of the interview forms were checked by experts of the field. The qualitative data was analyzed through content analysis. In the first place, data was coded, the themes emerged, the codes and themes were arranged by the researcher. As a final step, the findings were coded and interpreted. Based on the findings of the study, the strengths and weaknesses of the online curriculum were identified and a number of suggestions were offered based on the findings. The results of the study indicate that both learners and lecturers believe that online education is beneficial as well as productive and they are satisfied with the process. Online education was found to be preferable because it is time-saving, more economical, and flexible. On the other hand, limited interaction, unsustainable motivation, and problems caused by insufficient infrastructure were found to be negative aspects of online curriculum.
\end{abstract}

Keywords: Online education, online curriculum, curriculum evaluation

\section{Introduction}

Recently, there have been extensive changes in education during the 20th and 21 st centuries. The globalized world, which is changing emerging means of communication, is in a constant state of communication and information exchange, which greatly influences approaches to education. For example, as the gets smaller, more cultures come into contact and this brings to the fore the issue of information exchange. Therefore, topic-based approach gives way to interdisciplinary and intercultural approaches. This comes to mean that there are two fundamental pillars for intercultural and interdisciplinary planning. In addition, the close relation between knowledge and communication technologies makes the two terms highly important. It is known that life-long learning is on the increase in developed countries. Although schools are viewed as important sources of knowledge, they are not the sole places where learning takes place. Therefore, a new term is emerging "learning how to learn", which has been triggered by the developments in education and information technologies. Active learning, learning how to learn, electronic learning, learning usable information, computer based learning, distance education has become mainstays for the current approaches to curriculum development. Curriculum development has been extensively studied in relation to information technologies.

Current curricula focus on teaching and learning activities rather than elaborating on content in detail although there is a relative focus on determining the content in most curriculum development processes. Traditional curriculum development approaches are mainly based on the assumption that there should be a logical linear progression of the content to be taught and the content should be explicit. This might be valid for scientific and technological subjects. Yet, there may still be debate as regards the psychology behind the learning of these concepts. This means initiating the learning curriculum based on the interest of learners and moving into the underlying logical structure. Fundamental concepts may at times be hard for learners. For example, terms like "timber" or "glass" may turn out to be complex concepts in a chemistry class (Nearly, 2002, Devedižić, 2006; Hamee, Badii and Cullen, 2008).

There is no doubt that the opinions of practitioners vary widely as regards the importance attached to the different aspects of the planning and application processes of a curriculum, and the psychology of learners. With the rise of young researchers, significant developments took place in the field. Some of them are iterated below (Neary, 2002, 57): 
- $\quad$ identifying the needs in terms of course content: the importance of new and emerging skills

- defining the content need of the curriculum and attaching more importance to fair and reliable assessment

- defining the importance of the learning process besides learning outcomes

- the importance attached to the active participation of the learner

- the importance attached to both teacher-centeredness and student-centeredness

In short, it can be said that in curriculum development, life-long learning, information technologies play a crucial role (Huddleston and Unwin, 2002; Akkuş, 2008; Badrul and Mohamed, 2015).

Learning how to learn can be defined as learning by oneself based on students' using metacognitive thinking skills. Developments in information technologies lead to the development of new learning and teaching environments. Among these are computer-based learning, distance education, online learning and electronic learning (Alessi and Trollip, 2001; Dietinger, 2003; Mu and Ding, 2005; Yanpar, 2006).

The recent technological developments, the widespread use of computers and the Internet, lead to significant developments not only in industry but also in education. It must be emphasized that information technologies and e-learning play a significant role. In particular, with the rise of online learning, traditional ways of teaching and learning may appear to be expensive and demanding. E-learning, or electronic learning, is a term used to define concepts like web-based learning, virtual class environments, learning from CD / DVD, Internet-based learning. The purpose in these teaching and learning environments is to equip learners with necessary knowledge and skills (Bigdoli, 2004).

Viewed as the most powerful communication tool, the Internet brought a new dimension to education. While forming a variety of learning models, the Internet has also brought new dimensions to individuals' learning strategies and motivations. The Internet-based education, which resulted from the rapid integration of the Internet in education processes, turned the unilateral interaction model of the 1800s into bilateral interaction model (Gürol and Sevindik, 2001). The term online education, which enables two-way communication among teachers and students, was popular during the 2000s (Cinkara and Bağceci, 2013). The rapid development of information technologies at the end of the $21^{\text {st }}$ century and their becoming a part of daily life paved the way for the rise of online curricula (Ergül, 2006).

\subsection{Online Learning}

Online learning takes place through computer networks. The teacher and teaching techniques are connected to terminals by means of computer networks. They make synchronous or synchronous teaching possible (Race, 1999).

No matter where courses are conducted, in a short time the need for Web or Internet based materials besides course books will be felt. Since technology makes it possible to work with multimedia, it will provide more information in different formats. Working with technology and integrating it into education curricula has become an indispensable component of education process. Whether online or face to face, students must be in close connection with course materials (Porter, 2004).

From this point of view, it can be argued that there are not actually huge differences between face to face education and distance education. In materials design, both in face to face education and online education, philosophy of education and students' needs should be taken into account. In the case of distance education, students may need a mentor to receive help (Porter, 2004).

\subsection{Curriculum Development in Online Education}

Planning in online education highly depends on the intended goals and the target audience. At that point, whether the course will be conducted online (synchronous or asynchronous) or not and if so how it will be done assumes great importance. Moreover, there are three important points to consider in Internet-based distance education. These are as follows:

- $\quad$ selecting the correct methods and techniques

- $\quad$ supporting the methods with the necessary Internet technologies

- $\quad$ providing technical support and employing efficient materials and teachers

There is no doubt that online education must be planned with utmost care and the resulting course design must be innovative and must be interactional. A constructivist course design could be employed. Each course must comply with the requirements of electronic course curriculum; therefore, sustainability can be ensured in courses and students can progress from lower level cognitive development to higher level cognitive development (Ornstein and Hunkins, 2010). 
All in all, it can be put forward that effective planning is a fundamental component of implementing a teaching program (Porter, 2004).

The present study focuses on an online curriculum that was designed for an exam preparation process. The study evaluates the online curriculum based on the views of the learners and instructors.

\subsection{Aims of the Study}

The fundamental aim of the study is to find out the views of teachers and students enrolled in the online curriculum and conduct evaluation based on these views so that the strengths and weaknesses of the curriculum can be identified. To this end, the following research questions were formulated:

1. What are the views of learners enrolled in the online education in terms of the strengths and weaknesses of the curriculum?

2. What are the views of instructors in the online education in terms of the strengths and weaknesses of the curriculum?

3. What are the suggestions of learners and instructors as to the efficiency of the online curriculum?

\subsection{Limitations of the Study}

Basically, there are two limitations of the study. In the first place, the study group consists of 107 participants. The number of instructors was 11.

\section{Method}

\subsection{Research Design}

The present study is descriptive in nature and employs a survey method.

\subsection{Participants}

The participants of the study were 107 students, who are enrolled in the online education curriculum. All the participants are teacher candidates. They are supposed to take the Public Personnel Selection Examination to become teachers. They are all graduates of education faculties from different universities. Some of the participants chose not to answer the questions and they were not included in the study. In addition, 11 of the instructors were contacted and interviewed on the efficiency of the curriculum. The reason why there are 11 instructors is that there are 11 different parts in the exam. These parts or lessons are history, geography, citizenship, Turkish language, mathematics, which are termed as the general culture component, and curriculum development, teaching principles and methods, developmental physchology, psychology of learning, testing and assessment, guidance, which form the educational sciences component.

\subsection{Data Collection}

Qualitative means of data collection were employed in the data collection process. Learner interview form and instructor interview form were used. The interviews were conducted face to face with teachers. With the learners, all the interviews were conducted on the phone. The interviews generally lasted for 7 to 10 minutes. Instructor interviews lasted for 10 to 15 minutes. The interviews were recorded and then transcribed.

\subsubsection{Student Interview Forms}

In order to collect the views of the participants, "student interview form" was prepared and expert opinion was obtained in order to ensure realiability. Four questions were directed to the participants. These are open-ended questions and based on their results codes were identified. The four questions that were directed to the participants are as follows.

1. How did you find the online curriculum?

2. What are your views on the effectiveness of the online curriculum?

3. What are the strengths and weaknesses of online education in relation to face-to-face education?

4. What are your general views as to the learning process?

\subsubsection{Lecturer Interviews}

In order to draw comparisons between the views of the participants and instructors and decide on the effectiveness of the online curriculum, "instructor interview form" was developed. Expert opinion was obtained to ensure the 
reliability of the instructor interview form. Interviews were conducted face to face and recorded. The recorded interviews were converted into electronic data.

The questions that were directed to instructors are as follows:

1. How did you find the online curriculum?

2. What are the strengths and weaknesses of online education in relation to face-to-face education?

3. What is the influence of online education on the learning atmosphere?

4. What are your suggestions for a better online curriculum?

\subsection{Data Analysis}

Qualitative research can be defined a research design in which interviews, observations, and document analyses are employed and which aim to find out phenomena in naturally occurring environments in a realistic and holistic manner (Yıldırım ve Şimşek, 2013). In the present study, for the qualitative data, which was collected through interviews, descriptive method was used. Frequencies were calculated where necessary and used in the interpretation of the data. The following steps were followed for the qualitative data analysis in the study:

- $\quad$ processing data

- $\quad$ coding the data

- $\quad$ interpreting the data

\subsubsection{Coding the Data}

Data coding is used in order to extract important points. There are three stages to this process. In the first stage, concepts found in the data are identified. In the second stage, relationships among the variables are determined. In the third stage, these relations are explained (Punch, 2013). In the present study, concept-based coding was conducted. Descriptive analysis was conducted in order to interpret the data.

\subsubsection{Descriptive Analysis}

In this approach, data are analyzed based on pre-determined themes. In descriptive analysis, direct quotations are used so that important points can be more strikingly highlighted. The aim of this analysis is to present the data in an organized and neat manner. As such, the data are described systematically. As a next step, these descriptions are interpreted, possible causal relations are sought, and a number of conclusions are drawn. Relating the emergent themes, interpreting them and conducting projections as to the future directions are also among the aims of this analysis (Yıldırım and Şimşek, 2013).

Based on the data, the following themes emerged:

- Views regarding the instructional process

- The strengths of online education on face to face education

- The weaknesses of online education compared to face to face education

- $\quad$ Points favored by the participants as to the effects of online education

- Criticisms regarding the effectiveness of the online education

The following themes emerged out of the interviews conducted with instructors:

- Views of instructors as regards the online education process

- Views of instructors as regards the weaknesses of online education as compared to face to face education

- Views of instructors as regards the strengths of online education as compared to face to face education

- The positive contributions of online education to the learning process

- The negative effects of online education to the learning process

- $\quad$ The suggestion of the instructors as regards the online education process

The findings were interpreted based on these themes. The analyses were tabulated and explained.

\section{Findings and Interpretation}

Out of the 160 students, the number of participants who were interviewed through the interview form is 107 (66,9\%). The number of the participants who stated that they were satisfied with the online education was calculated as $57,9 \%$ 
(11,2\%, and $46,7 \%$, respectively). $4,7 \%$ of the participants stated that they were partially satisfied with the curriculum and $3,7 \%$ of the them stated that they were not satisfied with the curriculum. Thus, the $33,6 \%$ of the participants did not provide any answer for this question. The results of the interviews conducted the evaluate the efficiency of the online curriculum are presented below.

Table 1. Participant views on the online curriculum and the process

\begin{tabular}{|c|c|c|}
\hline THEMES, CODES, AND SUB-CODES & $\mathbf{N}$ & VIEWS \\
\hline \multirow{3}{*}{$\begin{array}{l}\text { user views as regards the online education } \\
\text { curriculum }\end{array}$} & & I liked it \\
\hline & 65 & I was satisfied. \\
\hline & & I didn't like it. \\
\hline \multirow{6}{*}{$\begin{array}{l}>\text { Satisfaction with the curriculum } \\
>\text { Time management } \\
>\quad \text { Adaptation } \\
>\text { The advantages }\end{array}$} & 5 & I wasn't satisfied with it. \\
\hline & & I couldn't concentrate and study. I had adaptation problems. \\
\hline & 3 & \\
\hline & 1 & I think I saved time. \\
\hline & 1 & $\begin{array}{l}\text { It is highly efficient for those who cannot attend face to face } \\
\text { education. }\end{array}$ \\
\hline & 1 & not bad \\
\hline
\end{tabular}

When we examine Table 1, we can see that 65 participants stated that they were satisfied with the online education curriculum. The views of the participants obtained from the third question were subjected to descriptive analysis. The answers provided by the participants were calculated in the form of frequencies. For this question, $64,5 \%$ of the participants provided valid answers. Table 2 presents the results. For the $3^{\text {rd }}$ question, which was asked so as to get an understanding of the strengths and weaknesses of online education, $64,5 \%$ of the participants stated their views.

Table 2. Participant views regarding the strengths and weaknesses of online education compared to face to face education

THEMES, CODES, AND SUB-CODES

The strengths of online education as opposed to face to face education

$>$ Time saving

$>$ The facility of re-watching lessons

$>$ The course atmosphere

$>$ Time management and advantage

$>$ Flexible hours

$>$ Transportation consitions

$>$ Focusing

$>$ Economic conditions

N VIEWS

14 The facility to watch and re-watch couses is strength.

$>$ Comfort

It is clear from Table 2 that $30 \%$ of the participants have positive views as regards online education as it provides flexible class hours and asynchronous viewing facility. These are viewed as the strengths of online education over face to face education. 
Table 3. The weaknesses of online education as opposed to face to face education

\begin{tabular}{|c|c|c|}
\hline $\begin{array}{l}\text { THEMES, CODES, AND SUB-CODES } \\
\text { the weaknesses of online education as opposed to } \\
\text { face to face education }\end{array}$ & $\mathbf{N}$ & VIEWS \\
\hline \multirow{10}{*}{$\begin{array}{l}>\text { The problem of dialogue } \\
>\quad \text { Communication and interaction } \\
>\quad \text { The facility of asking questions } \\
>\quad \text { Adaptation and motivation } \\
>\quad \text { The application of model tests } \\
>\quad \text { Negative influence } \\
>\text { The technical structure of the system }\end{array}$} & 11 & $\begin{array}{l}\text { It is not possible to get answers to questions } \\
\text { on the spot and posing questions in written } \\
\text { format leads to misunderstandings. } \\
\text { Sometimes, some questions are not } \\
\text { answered. In face to face education, it is } \\
\text { possible to get answers to questions. }\end{array}$ \\
\hline & 10 & $\begin{array}{l}\text { There are few opportunities to ask one to } \\
\text { one questions and get answers. }\end{array}$ \\
\hline & 8 & $\begin{array}{l}\text { There is a lack of communication between } \\
\text { the instructor and the student. }\end{array}$ \\
\hline & 3 & $\begin{array}{l}\text { It is difficult to concentrate in front of the } \\
\text { computer. }\end{array}$ \\
\hline & 3 & $\begin{array}{l}\text { There are some problematic parts in model } \\
\text { tests. }\end{array}$ \\
\hline & 2 & $\begin{array}{l}\text { Technical infrastructure } \\
\text { corrected. }\end{array}$ should be \\
\hline & 1 & Instructors do not care for students much. \\
\hline & 1 & $\begin{array}{l}\text { Online education causes laziness in the } \\
\text { brain. }\end{array}$ \\
\hline & 1 & There are no study hours. \\
\hline & 1 & $\begin{array}{l}\text { I can't get answers for my questions that I } \\
\text { pose through mail. }\end{array}$ \\
\hline
\end{tabular}

Table 3 shows that students in online education mostly complain about not getting answers on time for their questions and misunderstandings. Students find it difficult to ask questions and the reason for this is writing questions through the keyboard, which takes time or which may be missed by the lecturer. The answers given to questions 2 and 4 were subjected to content analysis. The following frequencies were obtained for questions 2 and 4. $46,7 \%$ of the participants expressed positive attitudes and views in favor of online educations. The percentage of those who stated that they had partially positive views was 6,5. In contrast, 9,3\% of the participants expressed negative views as regards online education and $37,4 \%$ of the participants did not provide any answers for these questions. 
Table 4. The strengths and weaknesses of online education from the viewpoint of the paticipants

\begin{tabular}{|c|c|c|}
\hline THEMES, CODES, AND SUB-CODES & $\mathbf{N}$ & VIEWS \\
\hline the imnacts of online education on the & 21 & $\begin{array}{l}\text { It has great contributions to learning and the education } \\
\text { process. }\end{array}$ \\
\hline instructional process & 13 & The system is higly successful. \\
\hline & 11 & I had a productive learning process. \\
\hline The quality of the system and satisfaction & 10 & The instruction and system are of high quality \\
\hline$>\quad$ Productivity in the learning process & 9 & It is an opportunity for students who can't attend face to \\
\hline The contributions to learning and education & & face courses. \\
\hline Opportunities for users and its advantages & 9 & The instructors are effective and can address all levels. \\
\hline Memorability & 7 & I liked it very much. \\
\hline The quality of the instructor and lecture & 5 & It is a very effective system. \\
\hline The qualities of courses & 4 & The presentations and lectures are memorable. \\
\hline$>\quad$ Interaction & 4 & The facility to watch courses asynchrounously has a great \\
\hline$>\quad$ The evaluation process & & impact. \\
\hline & 3 & $\begin{array}{l}\text { Students who follow synchronous courses will benefit } \\
\text { greatly. }\end{array}$ \\
\hline & 3 & It is not different from face to face education. \\
\hline & 2 & It was higly beneficial for my learning. \\
\hline & 2 & Mathematics courses were very effective. \\
\hline & 1 & There was interaction. \\
\hline & 1 & $\begin{array}{l}\text { I believe that it was especially beneficial for the } \\
\text { geography course. }\end{array}$ \\
\hline & 1 & It is financially more convenient. \\
\hline & 1 & or comfort. \\
\hline
\end{tabular}

Table 4 presents the views of the participants in terms of the strengths and weaknesses of the online curriculum. The results indicate that one of the most important findings is that online education has a tremendous contribution to the learning process. The other important contribution of online education is that it is rather economical and enables people to follow courses at the comfort of their houses. Table 5 presents the negative views of the participants as regards the online educations. One of the most frequently expressed limitations of online education is that courses are conducted rather superficially and lecturers may sometimes not be able to follow the flow of the online chat facility. 
Table 5. Participant views regarding the use of online education on the learning process.

\begin{tabular}{|c|c|c|}
\hline $\begin{array}{l}\text { THEMES, CODES, AND } \\
\text { SUB-CODES }\end{array}$ & $\mathbf{N}$ & VIEWS \\
\hline \multirow{2}{*}{$\begin{array}{l}\text { the impact of online learning on } \\
\text { the learning process }\end{array}$} & 6 & $\begin{array}{l}\text { Lectures were rather superficial. No details were addressed. The subjects } \\
\text { could have been lectured in more detail. }\end{array}$ \\
\hline & 6 & $\begin{array}{l}\text { More than one student asks question during the lessons at the same time, } \\
\text { and lecturers cannot follow these questions and answer. }\end{array}$ \\
\hline \multirow{3}{*}{$\begin{array}{l}>\quad \text { Interaction } \\
>\quad \text { Lectures and duration of } \\
\text { courses }\end{array}$} & 4 & It is not the same as face to face education. \\
\hline & & It is not as successful as face to face education. \\
\hline & 4 & $\begin{array}{l}\text { The lecture subjects were different from the ones in the books. Some } \\
\text { subjects were missing. }\end{array}$ \\
\hline \multirow{3}{*}{$\begin{array}{l}>\quad \text { The scope of courses } \\
\text { questions and the process of } \\
\text { initiating interaction }\end{array}$} & 3 & Communicatin is not satisfactory. \\
\hline & 2 & Each student's understanding capacity must be addressed. \\
\hline & 2 & Online questions must be explained. \\
\hline $\begin{array}{l}\text { The level of lectures and } \\
\text { learning }\end{array}$ & 2 & The fact that there are no test sections negatively affects the process. \\
\hline \multirow{5}{*}{$\begin{array}{l}>\quad \text { The lecturer } \\
\text { Online questions } \\
\text { one evaluation process of } \\
\text { online education in relation to } \\
\text { face to face education }\end{array}$} & 2 & Courses were finished before the due hour. \\
\hline & 1 & The shifts in lecturers were my main dissatisfaction point. \\
\hline & 1 & Some lecturers do not have experience. \\
\hline & 1 & The courses for the final groups must be started earlier. \\
\hline & 1 & Bir hocanın değişmesiyle eğitim daha kaliteli olabilir. \\
\hline \multirow[t]{4}{*}{$>$ Exams } & & By chanings, insufficient techers, the education process can be improved. \\
\hline & 1 & Unnecessary questions can be eliminated. \\
\hline & 1 & $\begin{array}{l}\text { Beyni tembelleştirdiğini düşünüyorum. } \\
\text { I belive that it makes the brain lazy. }\end{array}$ \\
\hline & 1 & y problem. \\
\hline
\end{tabular}

We can understand from Table 5 that one area of dissatisfaction on the part of the participants is lack of details in courses. In addition, the participants also voiced compaints as to the lack of content.

Another area of dissatistaction among the participants is tha they cannot get answer to their questions because to many students attempt to ask questions at the same time. This finding is in line with the finding of the previous part. In Table 3, one of the criticisms of the participants was that "I cannot easily get answers to my questions; questions are misunderstood because we write them. Answers come too late.". Therefore, we can speculate that communication issues seem to have more of a negative impact on the teaching and learning process in online education.

One of the weaknesses mentioned in Table 3 is not receiving answers to questions instantly. There are a number of issues that may lead to this problem. In the first place, students write at the same time and this makes it difficult for the lecturer to follow. This adversely affects the interaction among students and lecturers, which is another issue mentioned in Table 3. Since interactin is of huge significance in teaching and learning process, this problem may hinder the learning process.

From the perspective of the participants, another important point is that online education cannot be the same as face to face education. Most students may wish to have classroom environment. Lack of interaction is also one of the problems mentioned by the participants. Finally, lack of a model test was also one of the problems.

\subsection{The Evaluation of the Lecturer Interviews}

The number of lecturers teaching in the online education system is 15 and 11 of them were interviwed. The interviews were conducted with letueres who teach the general culture and capabilities component. 2 of the participants failed to attend the interviews. Therefore, 9 interviews were conducted. All interviews were conducted face to face and recorded.

Table 6 presents the results of the question: "How did you find the online educatin?". The results are coded. When we examine the views in Table 6, it can be understood that lecturers have a positive attitude towards online education. 
The percentage of those who believe that online education is a great opportunity for those who cannot attend face to face education is 33 . The lecturers in the study also stated that online education facilitates the learning process on the part of students.

Table 6. Lecturers' views on the online education process

$\begin{array}{lllll}\text { THEMES, } & \text { CODES, AND } & \mathrm{N} & \text { VIEWS } \\ \text { SUB-CODES } & \end{array}$

3 It is a great opportunity for those who cannot attend face to face education for any reason.

3 I think that it is rather different than classroom environment.

the views of the curriculum in 2 We can reach the lecturers from our houses, rooms and we follow courses general comfortably in our houses.

2 I think that it is very successful.

The teaching and learning atmosphere

2 Besides being the best education platforms, it also holds promise for the future of education.

$>$ The implementation

\begin{tabular}{ll}
\hline 2 & Online education gives us the chance to reach all parts of Turkey. \\
\hline 1 & $\begin{array}{l}\text { It is a highly effective means of education. It boths supports visual and } \\
\text { written education. }\end{array}$ \\
\hline 1 & It is a different and extraordinary implementation in the area of education. \\
\hline 1 & $\begin{array}{l}\text { It is an effective method in improving students' individual learning } \\
\text { process. }\end{array}$
\end{tabular}

On the other hand, $33 \%$ of the participants believe that online education is not the same as face to face education. There may be some prejudices against online education. However, a significant number of the participants stated that through online education they could reach all parts of Turkey and it fosters students' creativity and individual development.

Table 7. Lecturer views on the strengths of online education according to the lecturers compared to face to face education

\begin{tabular}{|c|c|c|}
\hline $\begin{array}{l}\text { THEMES, } \\
\text { SUB-CODES }\end{array}$ & $\mathbf{N}$ & VIEWS \\
\hline \multirow{2}{*}{$\begin{array}{l}\text { The strengths of online education } \\
\text { according to the lecturers }\end{array}$} & 6 & Students can watch courses asynchronously. They can revise. \\
\hline & 3 & Students can overcome psychological borders and ask questions. \\
\hline \multirow{6}{*}{$\begin{array}{l}>\quad \text { It is beneficia for lecturers } \\
>\quad \text { The versatility of the curriculum }\end{array}$} & 2 & It saves time and money. \\
\hline & 2 & It visually provides a rich learning atmosphere. \\
\hline & 1 & It is also beneficial for lectuere in terms of using time efficiently. \\
\hline & 1 & $\begin{array}{l}\text { While we cannot find time to solve tests in face to face education, } \\
\text { we can do that in online education. }\end{array}$ \\
\hline & 1 & The learning process in online education is faster. \\
\hline & 1 & orm wherever they want. \\
\hline
\end{tabular}

When we examine Table 7, 66,7\% of the participants stated that one of the most important strengths of online education aris that it makes it possible to watch course videos asynchronously and thus revise the course content. This view was also expressed in interview forms. This view was the most frequently expressed view. Thirty three percent of the lecturers stated that students could overcome their stress and ask questions, which is a positive aspect of online education according to them. A small part of the lecturers views the time-saving aspect of online education as a strength. Another important view voiced by the lecturers was that the content presented through online education could be visualized. Finally, the fact that one can enter online education from anywhere or at any time is another strength of online education. 
Table 8. The weaknesses of online education according to lecturers compared to face to face education

\begin{tabular}{|c|c|c|}
\hline THEMES, CODES, AND SUB-CODES & $\mathbf{N}$ & VIEWS \\
\hline \multirow{11}{*}{$\begin{array}{l}\text { The weaknesses of online education } \\
\text { according to lecturers } \\
>\quad \text { Feedback for questions } \\
>\quad \text { Lack of interaction } \\
>\quad \text { Students attitudes } \\
>\quad \text { Adverse conditions that may arise in } \\
\text { the teaching atmosphere }\end{array}$} & 4 & $\begin{array}{l}\text { Sometimes, students write at the same time and this causes } \\
\text { confusion. }\end{array}$ \\
\hline & 2 & $\begin{array}{l}\text { Since students cannot see the lecturer, the quality of the } \\
\text { interaction cannot be decided upon. }\end{array}$ \\
\hline & 1 & Sometimes, I answer questions very late. \\
\hline & 1 & $\begin{array}{l}\text { When effective interaction is not established, students may not be } \\
\text { able to express their ideas very clearly. }\end{array}$ \\
\hline & 1 & $\begin{array}{l}\text { the fact that students connect to the system individually rather } \\
\text { than as a whole }\end{array}$ \\
\hline & 1 & Students may have motivation problems. \\
\hline & 1 & $\begin{array}{l}\text { Lecturers may turn out to be passive in establishing the education } \\
\text { atmosphere. }\end{array}$ \\
\hline & 1 & $\begin{array}{l}\text { Students are devoid of the real atmosphere of a classroom and this } \\
\text { hiner the socialization process. }\end{array}$ \\
\hline & 1 & There may be problems due to Internet providers. \\
\hline & 1 & $\begin{array}{l}\text { Sstudents may face problems related to time as they are watching } \\
\text { videos asynchrounously. }\end{array}$ \\
\hline & 1 & The fact that couses are conducted in the evening. \\
\hline
\end{tabular}

Table 8 indicates that the negative aspects of online education center around 4 major issues. These are; (1) feedback for questions, (2) lack of interaction, (3) attitudes of students, and (4) problems pertaining to the teaching atmosphere. Almost half of the participants (44\%) stated that it is difficult to follow the flow of messages and sometimes we fail to see what students write. Another group (22\%) stated that the fact that students cannot see the lecturer is a disadvantage. This hinders effective communication.

Table 9. Lecturer views on the positive impact of online education on the teaching atmosphere

\begin{tabular}{lll}
\hline THEMES, CODES, AND SUB-CODES & N & VIEWS \\
\hline $\begin{array}{l}\text { The positive impact of online education } \\
\text { on the teaching atmosphere }\end{array}$ & 3 & $\begin{array}{l}\text { Since lessons are recorded, it is very easy to watch the lessons } \\
\text { asynronously, which renders reinforcement possible. }\end{array}$ \\
\cline { 2 - 3 } $\begin{array}{l}\text { Factors that facilitate learning } \\
\text { The influence of the system on the } \\
\text { individual }\end{array}$ & 3 & I believe that it has facilitating effect on learning. \\
\cline { 2 - 3 } & 3 & $\begin{array}{l}\text { I can say that it has a positive influence on the learning process, } \\
\text { although not as much as face to face education. }\end{array}$ \\
\cline { 2 - 3 } & 2 & More than one stimulant is at work, which activates students. \\
\cline { 2 - 4 } & 1 & Individual learning is accentuated through online education. \\
\cline { 2 - 3 } & 1 & Complementing the process. \\
\cline { 2 - 3 } & 1 & Individuals' own houses have a encouraging effect. \\
\cline { 2 - 3 } & 1 & $\begin{array}{l}\text { visualization as technical infrastructure and the positive influence } \\
\text { of visual on learning }\end{array}$
\end{tabular}

Table 9 presents lecturers' views in terms of the positive impact of online elarning. Views in Table 9 were characterized as "factors that affect learning" and "the influence of the system on the individual". It can be seen that $33 \%$ of the participants being able the re-watch the lesson videos asynchrounously empowers the learning process. The following quotation conscisely summarizes the general perspective of lecturers on the positive sides of online learning:

Lecturer: The fact that one can follow lessons live or asynchronously and the fact that one can adjust his or her own pace are important contributions of online education. This way we do not fal behind the current technological developments. Another benefit is that online learning gives you the comfort of your home and has an encouraging effect. 
The percentage of the lecturers who believe that it has a positive effect is 33 . Another $33 \%$ thinks that it has a positive effect, albeit not as much as face to face education. $22 \%$ of the lecturers stated that exposing students to more than one stimulant will undoubtedly reinforce learning. In sum, the positive sides of online education can be listed as follows:

- With online education, individual learning is ensured.

- Meeting the expectations of students

- The fact that it encourages learning at home

- Visualization as instructional infrastructure and the positive influence of visuals on learning

Table 10. Lecturer views on the negative impact of online learning on the learning process

\begin{tabular}{|c|c|c|}
\hline THEMES, CODES, AND SUB-CODES & $\mathbf{N}$ & VIEWS \\
\hline \multirow{2}{*}{$\begin{array}{l}\text { the effects of online learning on the learning } \\
\text { process }\end{array}$} & 1 & working with a huge number of students \\
\hline & 1 & Learning definitely takes place in \\
\hline Negative effects & & environment. \\
\hline & 1 & Interaction is too weak. \\
\hline
\end{tabular}

Table 10 demonstrates that "dealing with a huge number of students" is one of the major issues affecting the learning process negatively. This can be viewed as the underlying reason behind the problems mentioned above. In online education, the participants, both students and lecturers, try to communicate in a different platform; they try to establish a dialogue through online means and this may pose problems. This may cause dissatisfaction on the part of some users.

Table 11. Lecturer views on the process of the online education process

\begin{tabular}{|c|c|c|}
\hline THEMES, CODES, AND SUB-CODES & $\mathbf{N}$ & VIEWS \\
\hline \multirow[t]{2}{*}{$\begin{array}{l}\text { Instructor views on the process of the online } \\
\text { education process }\end{array}$} & 6 & $\begin{array}{l}\text { For the online education to be more successful, more student } \\
\text { participantion should be ensured. }\end{array}$ \\
\hline & 3 & The number of students in sessions should be reduced. \\
\hline$>\quad$ Student participation & 2 & The infrastructure should be empowered. \\
\hline \multirow[t]{2}{*}{$\begin{array}{l}\text { The questionable quality of } \\
\text { presentations }\end{array}$} & 2 & $\begin{array}{l}\text { The presentations conducted by instructors should be visualized } \\
\text { as much as possible. }\end{array}$ \\
\hline & 1 & The presentations can be conducted by more than one person. \\
\hline
\end{tabular}

Table 11 presents participants views as regards the instructional process in the online curriculum. It can be understood from the table that for the online education to be more successful, $66,7 \%$ of the participants stated that student participation should be ensured. Secondly, 33\% of the participants suggested that the number of students in online sessions could be reduced. Twenty two percent of the participants put forward suggestions regarding the system itself. They suggested that the curriculum could be much more productive on condition that the problems are eliminated in the system. Finally, $22 \%$ of the participants stated that the presentations conducted in courses should be visualized as much as possible.

\section{Discussion and Conclusion}

This part of the study presents the results obtained through interview forms and lecturers' views. The findings can be listed as follows:

Majority of the students found the online education satisfactory. It should not be disregarded that technological facilities play a critical role in the affective factors and learner readiness. It is emphasized in literature that access to technology, technological skills, motivation and the usefulness of e-learning environments affect learner readiness (Watkins, Leigh and Triner, 2004, Kırmız1, 2015).

Both students and lecturers found the online education was beneficial and stated that it contributed to the learning process. The content is presented in an easily accessible manner and this enables students to be able to attend lessons from anywhere; this can be seen as an advantage. Since the present study was a qualitative study, the influence of age, gender or previous learning experiences in online education was not investigated. This is because these variables were investigated in previous studies and no statistically significant difference was found between age, gender, or previous online learning experiences and expectations of students, preferences, or satisfaction (Paechter, Maier and 
Macher 2010).

It was found out that online education has a number of strengths over face to face education. As is indicated in literature, re-watchiing videos, or the facility to follow asynchrounous sessions are among the most important aspects of online education (Kaya, 2002; Akın, 2007). Online education makes it possible to reach all parts of Turkey and thus students in rural areas can also benefit from this education. The fact that students can watch lesson video later and thus reinforce their learning is another advantage of online education over face to face education. It can be asserted that online education has a facilitating effect on learning. The fact that visualization is extensively used in online education makes it an effective means of presentation. Both lecturers and students enjoyed this facility. Another positive finding of the present study was that the participants believe that the learning process was productive. According to Özer (1990), students in online education are generally motivated students. The fact that students attend online courses voluntarily, the facility to follow courses along with business life, and the fact that students will be rewarded with better working conditions contribute to motivation. In addition, the online curriculum is tailored to all levels. Users believe that the way lecturers conducted the lessons was memorable.

The advantages online education confers in terms of time and money make it preferable for students. For most lecturers, online education is not different from face to face education on condition that effective communication is established. This finding is in line with the Schneller ve Holmberg's (2014) study. Their study found that online education is favorable for students since it provides flexibility in course hour, makes it possible to attend courses as they are working, and makes it easier fort hem to be pormoted (Hrastinski, 2007; Simonson, Smaldino, Albright and Zvacek, 2012; Firat, 2016).

Some problems may arise in online education as people try to communicate through the chat facility at the same time. Since the number of students in online education exeeds those in face to face education, problems arise in communication. Lecturers may not be able to follow the flow and fail to answer some stuents' questions. This decreases the satisfaction level of the participants. Since participants cannot see their interlocuters and their gestures or body language, lecturers may have hard times in understanding whether students grasped the content or not. This indicates the relative inefficiency of the communication process. These findings are supported by the study conducted by Özköse, Arı ve Çakır (2013), in which they carried out SWOT analysis to find out the strengths and weaknesses of online education.

Some students may find it hard to concentrate on courses from home. This, in turn, leads to loss of motivation. Some students stated that lecturers were changed from time to time and this led to difficulties in adjusting to new lectures, which is another source of dissatisfaction. If effective interaction is established, students can get rid of their shyness and ask questions. There may be technical problems. Online lessons are not conducted as detailed as face to face courses. Students complained about lack of sufficient time devoted to tests.

In literature, there are studies that point out limitations like these. A study conducted by Kaya (2002) and Çakır (2013) came up with similar results. Bostock's (1997) carried out a study with 285 learners and 12 lecturers and found that the use of technology and the Interent in the education process had negative effects on students. Due to these limitations, some researchers developed different online teaching models (Moore and Marra, 2005; Janssen, Erkens, Kanselaar and Jaspers, 2007; Pala and Erdem, 2011).

\section{Suggestions}

1. From the results, we can say that one of the most important problems is lack of effective interaction. This can be attributed to not being able to gestures or trying to convey messages through the keyboard. Students may have variable efficiency in keyboard use. This prevents students from asking questions. Therefore, technical issues assume important.

2. Another suggestion can be to reduce the number of students because large classes hinder communication. It becomes difficult for the lectueres to follow students' messages and provide answers for their questions on time.

3. Online education makes it possible to follow lessons at the comfort of students' houses. However, some students find it hard to concentrate at home. This can be overcome by providing students the facility of online voice and use of visuals.

4. Some participants complained that some lectueres do not have sufficient experience. This problem can be overcome by getting lectuers to watch prior videos.

5. Variety should be ensured in the presentation of the content and presentation techniques. Creative and innovative activities or materials can be provided. 


\subsection{Suggestions for Further Research}

Out of the results of the present study, a number of suggestion can be made for further research. In the first place, the present study found that technical infrastructure plays an important role in the effectiveness of online education. In a further study, this can be studied in more detail and more suggestions can be drawn. In the present study, the suggestion was to improve voice and visual quality so that more learner participation can be ensured.

In another study, the impact of both synchronous and asynchronous online curriculum models can be compared and their efficiency can be investigated. In synchronous online education, the impact of class size on success can also be studied. This is because in the present study, it was seen that the nubmer of participants have an impact on a number of issues such as the quality of interaction.

Another idea could be to conduct studies that focus on finding out educational activities, instructional games or different interaction facilities and to test their viability so that better social interaction can be provided and couses can become more enjoyable.

\section{References}

Akın, M. (2007). The Effect of the utilisation of computer and Internet technology on the application knowledge: The case study of Erzincan Faculty of education Erzincan Üniversitesi, Erzincan University Journal of Faculty of Education, 9(2), 49-70

Akkuş, N. (2008). An evaluation of 2006 PISA results as an indication of lifelong learning. M.A. thesis: Hacettepe University Institute of Social Sciences: Ankara

Alessi, S. M. \& Trollip, S. R. (2001). Multimedia for Learning: Methods and Development. Allyn and Bacon: USA

Aşkar, P. (2003). Fundamental approaches to distance education and and being a student at online education (ed) Conference on distance education Technologies and technology-assisted education, Ankara

Badrul, H. K. \& Mohamed, A. (2015). International Handbook of E-Learning Volume 1: Theoretical Perspectives and Research, Routledge International

Bigdoli, H. (2004). The Internet Encyclopedia, John Wiley and Sons: Hoboken, New Jersey

Bostock, S.J. (1997). Designing Web-Based Instruction For active Learning, In B.H. Khan (ed.) Web-Based Instruction, p. 225-237, Englewood Cliffs, Educational Technology Publications

Bruer, J. T. (2003). Technology Applications in Education, A Learning View. Lawrence Erlbaum Associates Publisher: London

Brunton, K. (2006). Education for Sustainable Development: Principles for Curriculum Development in Business Subject Areas, Investigations in University Teaching and Learning, 3 (2) ISSN 1740-5106, 36-46

Cinkara, E. \& Bağceci, B. (2013). Learners' Attitudes Towards Oniıne Language Learning; And Corresponding Success Rate, Turkish Online Journal of Distance Education-TOJDE, 14 (2), Article 6

Devedižić, V. (2006). Semantic Web and Education. New York: Springer

Dietinger, T. (2003). Aspects of e-learning environments, Unpublished doctoral dissertation, Graz University of Technology, Austria

Ergül, H. (2006). The motivational constructs that predict success in online education, The Turkish Online Journal of Educational Technology - TOJET 5(1)

Firat, M. (2016). The paradigm change in higher education in the 21. century, Journal of Higher Education and Science, 6(2), 142-150. https://doi.org/10.5961/jhes.2016.151

Gürol, M. \& Sevindik, T. (2001). Internet Tabanlı Uzaktan Eğitim Uygulamaları, VII. Türkiye'de Internet" Konferansı. E-türkiye+: Türkiye'yi İnternete Taşımak. İstanbul

Hameed, Sh., Badii, A., \& Cullen, A.J. (2008). Effective E-Learning Integration with Traditional Learning in a Blended Learning Environment, European and Mediterranean Conference on Information System, Dubai.

Harasim, L. M. (1990). Online Education: Perspectives on a New Environment, Praeger: New York

Hrastinski, S (2008). A Study of Asynchronous and Synchronous E-learningmethods Discovered that Each Supports Different Purposes, Asynchronous \& Synchronous E-Learning. Educause Quarterly, 4 
Hrastinski, S. (2009). A Theory of Online Learning as Online Participation. Computers \& Education, 52(1), 78-8. https://doi.org/10.1016/j.compedu.2008.06.009

Huddleston, P. \& Unwin, L (2002). Teaching and Learning in Further Education: Diversity and Change. London: Routledge

Janssen, J., Erkens, G., Kanselaar, G., \& Jaspers, J. (2007). "Visualization of Participation: Does It Contribute to Successful Computer-supported Collaborative Learning?", Computers and Education, 49, 1037-1065 https://doi.org/10.1016/j.compedu.2006.01.004

Kaya, Z. (2002). Distance education. Ankara: Pegem A Yayıncılık

Kırmızı, Ö. (2015). The influence of learner readiness on student satisfaction and academic achievement in an online program at higher education, The Turkish Online Journal of Educational Technology (TOJET), 14(1), 133-142

Marsh, C. J. (2004). Key Concepts for Understanding Curriculum, New York: Routledge https://doi.org/10.4324/9780203326893

Mu, S., \& Ding, X. (2005). Cognitive Style Theory-Based Design and Implementation of Online Course. Paper presented at ICDE International Conference, New Delhi

Moore, J.L. \& R.M. Marra, (2005). A Comparative Analysis of Online Discussion Participation Protocols, Journal of Research on Technology in Education, 38 (2), 191-212 https://doi.org/10.1080/15391523.2005.10782456

Neary, M. (2002). Curriculum Studies in Post-compulsory and Adult Education, Cheltenham: Nelson Thornes.

Ornstein, A. C. \& Hunkins, F. P. (2010). Curriculum: Foundations, Principles and Issues, Pearson Educational Leadership7 edition: United States of America.

Özer, B. (1990). The universal structure of distance education, Anadolu Unıversity Online Journal of the Faculty of Communication Sciences, 8, 569-594.

Paechter, M., Maier, B., \& Macher, D. (2010). Students' Expectations of and Experiences in E-Learning: Their Relation to Learning Achievements and Course Satisfaction, Computers \& Education, 54, 222-229. https://doi.org/10.1016/j.compedu.2009.08.005

Özköse, H., Arı, S., \& Çakır, Ö. (2013). SWOT analysis for distance education, Middle Eastern \& African Journal of Educational Research, 5, 41-55

Pala, F. K., \& Erdem, M. (2011). Investigation of Participation in Student-led Online Discussion with Respect to Management Responsibility and Learning Styles, Hacettepe University Journal of Education, 41, 360-371

Porter, L. R. (2010). Developing an Online Curriculum: Technologies and Techniques, Information Science Publishing: USA.

Punch, K. F. (2013). Introduction to Social Research, Sage Publications Ltd: California

Race, P. (1999). 2000 Tips for Lecturers, London: Routledge

Romiszowski, A. \& Mason, R. (2004). Computer-mediated communication, In: Jonassen D. (eds), Handbook of Research for Educational Communications and Technology (2nd ed.). Lawrence Erlbaum, Mahwah NJ, $397-431$

Türkoglu, R. (2002). A sample web-based education practice, Journal of Politeknik, Vol. 5. N.3. 209-215

Türkoğlu, R. (2003). The processes of develooping Internet-based distance education curricula, The Turkish Online Journal of Educational Technology - TOJET 2(3), 116-126

Schneller, C., \& Holmberg, C. (2014). Distance education in European Higher Education: The Students. International Council for Open and Distance Education, UNESCO Institute for Lifelong Learning, and StudyPortals

Simonson, M., Smaldino, S. E., Albright, M. \& Zvacek, S. (2012). Teaching and Learning at a Distance: Foundations of Distance Education. Boston: Pearson Education, Inc

Yanpar, T. (2006). Educatinal technology and meterial design, Ankara: Anı Yayıncılık

Yıldırım, A. \& Şimşek, H. (2013). Research methods in social sciences, Ankara: Seçkin Yayıncılık

Watkins, R., Leigh, D., \& Triner, D. (2004). Assessing Readiness for E-learning. Performance Improvement Quarterly, 17(4), 66-79. https://doi.org/10.1111/j.1937-8327.2004.tb00321.x 